\title{
GCMの不確実性を考慮した気候変動がコムギ とトウモロコシの生産量に与える影響評価
}

\author{
辰己 賢一 ${ }^{*} \cdot$ 山敷 庸亮 $^{1} \cdot$ 寶 馨 $^{1}$ \\ 1京都大学防災研究所（†611-0011 京都府宇治市五ヶ庄） \\ * E-mail: tatsumi.kenichi.6m@kyoto-u.ac.jp
}

\begin{abstract}
CMIP3マルチ気候モデルによるSRES A1B, A2, B1シナリオに基づく出力值を農作物収量算定モデルの入 力值に用い，コムギ・トウモロコシの2040-2059年，2080-2099年における生産量の現在（1980-1999年）か らの変化を見積り, 気候変動が農業生産に与える影響を不確実性を考慮して評価した。コムギの地球全体 における生産量は近未来, 未来とも全シナリオ下で減少することが示され, 東アジアでは生産量が増加す る一方, 南アジアやヨーロッパでは大きく減少する結果を得た。 トウモロコシは現在の主要生産域での生 産量減少は微小な幅にとどまることがわかった。 B1シナリオでは将来における生産量変化のモデル間のば らつき，つまり不確実性の幅が最も小さい結果となった。
\end{abstract}

Key Words : CMIP3, SRES scenario, crop production, wheat, maize, iGAEZ, uncertainty

\section{1. はじめに}

地球温暖化の影響で気温や降水特性の変化が顕著にな ってきていると言われている. IPCC第4次評価報告書は, 21世紀半ば及び後期までの予測に基づいた極端な気象及 び気象現象の変化による寒冷環境での農作物収量の増加, 温暖環境での収量減少, 土袞の浸食・浸水などによる耕 作不能化を指摘している.

Takahashi et al. ${ }^{1}$ は，気温が $2^{\circ} \mathrm{Cから} 5^{\circ} \mathrm{C}$ 上昇すると，中国 におけるコムギの生産量は6割，トウモロコシは4割減少 するなど，アジアの穀物生産が大打撃を受けることにな ると推定した. Masutomi et al. ${ }^{2}$ は，SRES A1B, A2, B1の合 計49のGCM (General Circulation Model) 出力值を用いて, GCM出力の不確実性を評価するとともに将来気候がア ジア域におけるコメの収量に与える影響を評価した。 そ の結果，2081-2090年の平均収量は，1991-2000年平均に比

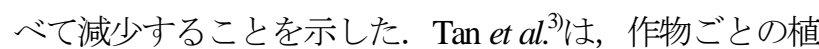
え付け期と収穫期を考慮した作物収量モデルEPICを用 いて主要穀物の収量計算を全球レベルで行い，温暖化が 多くの国で農作物生産に悪影響を与える可能性があるこ とを示した. Pary et al. ${ }^{4}$ はA1FI, A2, B1, B2シナリオ下での 主要穀物の収量変化を全球レベルで予測した。 その結果, $\mathrm{CO}_{2}$ 施肥効果のあるなしに関わらず，全球平均で穀物の 生産量は減少することを示し，B1, B2シナリオ下では,
先進国と発展途上国の将来の収量差がA1FI, A2シナリオ と比較して小さくなることを示した. Tatsumi et al..$^{5}$ は, 世界の主要穀物8種の収量再現計算とA1Bシナリオ下で の将来の収量予測をモデル計算により全球規模で行った. 以上の既往研究が示寸ように，将来の温暖化が農業生 産に与える影響に関する研究は数多く行われている。一 方，さまざまなモデルの入力值として用いられる将来気 候值は，各研究機関などによって作成されており， GCMに採用されている物理過程などはそれぞれ異なる ことが多く, 将来の社会シナリオごとに予想される $\mathrm{CO}_{2}$ 濃度や気候值の特徵もモデルによって異なる. 加えて, 既往研究では，モデル入力值として利用されている GCM出力の数や社会シナリオの数は現状では十分とは 言えず，将来の気候変動が農業生産に与える影響予測結 果の不確実性については十分な議論がなされているとは 言い難いのが現状である. 本研究では, 物理法則に従っ て将来の気象現象や気候要素が再現された世界気候研究 計画の第3次結合モデル相互比較プロジェクト $\left(\mathrm{CMIP}^{3}{ }^{6}\right)$ が提供する最大 240 気候モデルによるSRES A1B, A2, B1 シナリオに基づいて計算された出力值を農作物収量算定 モデルの入力值に用い，近未来（2040-2059年），将来 （2080-2099年）におけるコムギ・トウモロコシの生産量 の現在（1980-1999年）からの変化を推計した. 以上によ り, 気候変動が農業収量に与える影響を推定し, その不 
確実性を考慮した定量的な分析を行うことを目的とする.

\section{2. 利用データと不確実性の評価方法}

\section{(1) 入力気候データ}

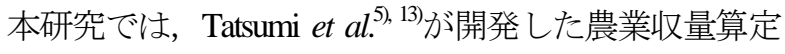
モデルiGAEZ (improved Global Agro-Ecological Zones )をべー スに用いる．iGAEZは気温，降水量，放射，土䁃の性質， 地形環境，技術発展のデータを取り入れて，それに対す る作物の生長・動向のモデル化により, 作物の収量を算 出するものである．また，約175の作物種（亜種を含む） に対応でき，地球環境と土地生産の関係に関寸る空間的 な考察と検討が可能である. 入力值として用いる現在気 候值（1980-1999年）にはCRU TS2.1 ${ }^{7}$ を，近未来（20402059年）および将来（2080-2099年）にはCMIP3マルチ気 候モデルのSRES A1B（高成長社会シナリオ）,A2（多元 化社会シナリオ）, B1（持続発展型社会シナリオ）シナ リオ下の気候值を用いた. CMIP3は, Program for Climate Model Diagnosis and Intercomparison (PCMDI) によりWEBで 公開されており，地球温暖化による影響評価に土地利用， 陸域生態系, 気象, 海洋, 水資源など様々な分野で用い られている. これらの気候モデルの水平解像度は $100 \mathrm{~km}-$ $450 \mathrm{~km}$ 程度で, 公開されているモデルは24種類であり, モデルによっては複数のアンサンブルランを実施してい る. 本研究で使用したマルチ気候モデルを表-1に示す.

\section{（2）気候シナリオの作成と収量推計手法}

GCMマルチ気候モデルの出力值と過去に得られた観 測気候值の間には系統的なバイアスを有していることか ら，1961-1990年の各月について，月平均值がCRU TS2.1 による值と一致するようにマルチ気候モデルの出力值に 補正を施した. 寸なわち, 月平均気温值についてはベー スライン期間（1961-1990年）のCRU TS2.1とマルチ気候 モデル出力の月平均值の差分（気候変化值）を気候モデ ル出力値に加算することにより作成した. 気温以外の物 理量については，気候モデル出力值がベースライン期間 の気候モデル出力の平均值以上の場合は, ベースライン 期間のCRU TS2.1と気候モデル出力の平均值の差分, 未 満の場合はその比を気候モデル出力值にそれぞれ加算・ 乗算することにより作成した ${ }^{2}$. また，入力に用いた月 別の気候データは，スプライン補間によって日別データ に変換した. また, 標高8) ・土壤タイプ9) ・ 灌溉率データ 10) ・農事暦データ11) は最短距離法を適用することにより, モデル入力に用いる全データの水平解像度を 0.5 度に統 一した. また, CMIP3マルチ気候モデル出力值はモデル ごとに解像度が異なるため, 本研究では気温に関しては
表-1 本研究で使用したCMIP3マルチ気候モデル

\begin{tabular}{|c|c|c|c|}
\hline \multirow[b]{2}{*}{ Model Name } & \multicolumn{3}{|c|}{ SRESシナリオ } \\
\hline & A1B & A2 & B1 \\
\hline BCCR-BCM2.0 & o & o & o \\
\hline CCSM3 & 0 & 0 & o \\
\hline CGCM3.1(T47) & ○ & $\circ$ & ○ \\
\hline C GCM3.1(T63) & 0 & & 0 \\
\hline CNRM-CM3 & ○ & $\circ$ & ○ \\
\hline CSIRO-Mk3.0 & 0 & o & 0 \\
\hline CSIRO-Mk3.5 & 0 & $\circ$ & 0 \\
\hline ECHAM5/MPI-OM & o & o & 0 \\
\hline ECHO-G & ○ & $\circ$ & ○ \\
\hline FGOALS-g1.0 & ० & & ० \\
\hline GFDL-CM2.0 & 0 & $\circ$ & 0 \\
\hline GFDL-CM2.1 & 0 & 0 & 0 \\
\hline GISS-AOM & o & & 0 \\
\hline GISS-EH & 0 & & \\
\hline GISS-ER & 0 & $\circ$ & 0 \\
\hline INGV-SXG & 0 & o & \\
\hline INM-CM3.0 & ○ & $\circ$ & ○ \\
\hline IPSL-CM4 & ○ & $\circ$ & ○ \\
\hline MIROC3.2(hires) & ० & & ० \\
\hline MIROC3.2(medres) & ० & $\circ$ & ० \\
\hline MRI-CGCM2.3.2 & ० & $\circ$ & $\circ$ \\
\hline PCM & 0 & 0 & o \\
\hline UKMO-HadCMЗ & ○ & $\circ$ & ○ \\
\hline UKMO-HadGEM1 & 0 & $\circ$ & 0 \\
\hline
\end{tabular}

スプライン補間，降水量に関しては逆距離加重法を用い て，0.5度の水平解像度にリグリッドした。 なお，本研 究ではA1Bシナリオとして24のモデル，A2シナリオでは 19のモデル，B1シナリオでは22のモデルを使用した（表 -1）. 将来の機械化効率は，村井ら ${ }^{12}$ による耕地面積あ たりトラクター台数と 1 人あたりGDPの回帰式から, 将 来の耕地面積あたりトラクター台数を算出する. FAOSTATのトラクター台数データと耕地面積データか ら，トラクター台数を耕地面積で除した值の1960-1969年 の平均を1とした各年における耕地面積あたりのトラク ター台数の比を国ごとに時系列で求め, iGAEZで得られ た作物収量值に乗じた. $\mathrm{CO}_{2}$ の施肥効果は, Masutomi et

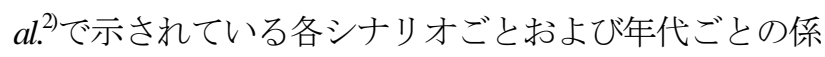
数を乗ずる. なお，将来における土地利用変化および灌 溉エリアの変化は不確実な要素が大きいため, 本研究で は現在から変化しないものと仮定した.

以上によりデータを整備した上でiGAEZを使用し，現 在(1980-1999年), 近未来(2040-2059年), 将来(2080-2099年) におけるコムギ・トウモロコシの収量を推計し，現在気 候下における収量再現性の精度 ${ }^{13}$ を確認した上で，気候 変動が作物収量に与える影響を評価した。

\section{(3) 不確実性の評価手法}

気候変動が農作物生産量に与える影響の不確実性を定 量的に評価するため, 以下に示寸指標を定義する゙2. 


$$
\begin{gathered}
A_{C P_{\mathbf{P}}}=\frac{1}{n} \sum_{\text {model }} C P_{\mathbf{p}, \mathbf{m}} \\
S D_{C P \mathbf{P}}=\sqrt{\frac{1}{n-1}\left\{\left(\sum_{\mathbf{m}} C P_{p, m}^{2}\right)-\frac{1}{n}\left(\sum_{\mathbf{m}} C P_{\mathbf{p}, \mathbf{m}}\right)^{2}\right\}} \\
P_{C P<0}=\frac{N U M_{\mathbf{m}}\left(C P_{\mathbf{p}, \mathbf{m}}<0\right)}{n} \times 100 \\
P R_{\mathbf{p}, \mathbf{m}}=\int_{\mathbf{c a}} \text { Yield }_{\mathbf{p}, \mathbf{m}} d A
\end{gathered}
$$

ここに, $C P_{\mathbf{p}, \mathbf{m}}$ : 現在(1980-1999年) からの近未来（20402059年），将来（2080-2099年）における生産量変化率 (\%) , $A_{C P \mathbf{p}}$ : 各シナリオ下におけるモデルごとの生産 量変化率の平均 $(\%), S D_{C P_{\mathbf{p}}}$ : 各シナリオ下におけるモ デルごとの生産量変化率の標準偏差, $P_{C P<0}$ : 各シナリオ 下においてモデルごとの生産量変化率が負になる割合 (\%),$P R_{\mathbf{p}, \mathbf{m}}$ : 各シナリオ下におけるモデルごとの生 産量 $(\mathrm{kg})$ を示し, Yield $\mathbf{p , m}$ : 各グリッド上の収量 $(\mathrm{kg} / \mathrm{ha})$ にPortmann et al. ${ }^{14}$ によるる各グリッドごとの収穫面積值を 乗じた值を地域ごとに合算して得る。 $n$ : 計算時に使わ れた各シナリオ下におけるGCMモデルの数. さらに, サフィックス $\mathbf{p}$ : 現在, 近未来, 将来の各期間, $\mathbf{m}$ : 計算 に使用した各モデル， ca: 現在の栽培エリアである.

\section{3. 結果と考察}

表-1に示したCMIP3マルチ気候モデル出力值を用いて A1B, A2, B1シナリオ下の近未来，将来におけるコムギ・ トウモロコシの生産量を推定し, 現在気候下の生産量か らの変化を求めた. 表-2, 表-3に地域別の生産量変化率 の平均 $A_{C P}$, 全モデル数に占める生産量変化率が負とな る割合 $P_{C P<0}$, 各モデルによる生産量変化率の標準偏差 $S D_{C P}$ を各作物ごとに示寸. 図-1にA1B, A2, B1における 将来の生産量変化率を箱髹図で各作物ごとに示す。

コムギの地球全体のGCM平均に見る生産量は近未来 のA1Bで7.2\%, A2で7.0\%, B1で6.7\%減少し，将来のA1Bで 9.8\%, A2で10.3\%, B1で7.8\%減少すると算定された．地域 別に見ると，ロシアではA1Bシナリオ下の近未来で $A_{c p}$

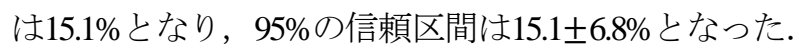
同様に将来における $A_{C P}$ は23.9\%, 95\%の信頼区間は

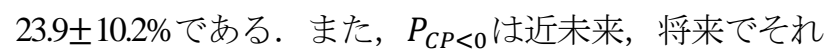
ぞれ12.5\%,8.3\%となった（表-2）。以上のことから，口
シアでは全シナリオ下において気温の上昇などが要因と なり生産量の大幅な増加が予想される結果となった. $S D_{C P}$ は，A1B，A2，B1シナリオ下の近未来でそれぞれ $16.0 \%, 12.5 \%, 14.1 \%$ となり，将来ではそれぞれ $24.2 \%$, 30.1\%, 14.2\%となり，他の地域に比べて相対的に大きく， また近未来と比べて将来の生産量変化率はより大きな不 確害性を持つことを示寸結果となった。これはロシアに おけるGCM気候值が各モデル間で大きなばらつきをも つことに要因があると考えられる. 一方, 現在の主要生 産域である東アジアでは，A1B, A2, B1それぞれの近未来 における生産量変化率は2.4\%, 2.7\%, 1.3\%と微増であり, 将来ではそれぞれ $1.6 \%, 0.6 \%, 0.8 \%$ となり，近未来と比較 して増加率が小さくなる．また， $P_{C P<0}$ の值は，近未来 の全シナリオ平均で $32.7 \%$, 将来で $44.0 \%$ となり, 減少寸 る確率が将来では40\%を超える結果となっていることか ら，この地域における将来の生産量の増減についてはど ちらの傾向が有意であるかを判断することが難しいこと がわかる. しかしながら, 東アジアの近未来, 将来にお ける本結果は，Lobell et al. ${ }^{15}$ の中国での2030年における生 産量の微増傾向を示寸結果と同じ傾向を示している. 南 アジアでは, 気温の上昇に伴ってA2シナリオ下の将来 では18.1\%の生産量減少を示寸結果となり, 他のシナリ 才下でも生産量は大きく減少する可能性が高いことがわ かった. また, 近未来, 将来ともに生産量が減少する確 率は80\%を超え，この地域における生産量の減少傾向を 示寸本結果は, Panry et al. ${ }^{4}$, Lobell et al. ${ }^{15}$ と同様の傾向を示 している. 世界最大の生産量を誇るヨーロッパにおける $P_{C P<0}$ の值を見ると，B1シナリオ下の近未来および将来 の北ヨーロッパを除いて，50\%以上の確率で将来の生産 量減少を示寸結果となり, 温暖化などによる生産量の減 少が将来の食糧需給に大きな影響を与える可能性が示唆 される結果となった. ヨーロッパ最大のコムギ生産国で あるフランスが属する西ヨーロッパでは, 将来の $A_{C P}$ は 全シナリオ平均で-11.5\%を示しており, 同様に $P_{C P<0}$ は 90\%を超えている. また, $S D_{C P}$ は9.8\%となり, 他の地域 に比べて相対的に小さい值を取っており, 各モデルによ る計算結果のばらつきは小さく, 将来における生産量の 減少が多くのモデルで示されていることがわかる（図1）。ヨーロッパでの生産量減少の傾向は, Pany et al. ${ }^{4} に$ よるA1F1, A2a, A2b, A2c, B1a, B2aにおいて $\mathrm{CO}_{2}$ の施肥効果 がない場合における収量減少を示寸結果と整合的である が，施肥効果を考慮した場合は，収量が増加すると予想 していることから，本結果との一致を見ない．

$A_{C P}$ の地域間標準偏差は, A1B, A2, B1シナリオ下の近 未来でそれぞれ $10.1 \%, 9.4 \%, 7.6 \%$ ，将来が $14.8 \%, 16.1 \%$, 11.4\%となり, 近未来と比較して将来では, 各地域間の 生産量変化率のばらつきが大きくなることが示された. 
表-2 各シナリオ下における近未来, 将来のコムギの $A_{C P}, P_{C P<0}, S D_{C P}$

\begin{tabular}{|c|c|c|c|c|c|c|c|c|c|c|c|c|c|c|c|c|c|c|}
\hline & \multicolumn{9}{|c|}{ 近未来 } & \multicolumn{9}{|c|}{ 将来 } \\
\hline & \multicolumn{3}{|c|}{ A1B } & \multicolumn{3}{|c|}{$\mathrm{A} 2$} & \multicolumn{3}{|c|}{ B1 } & \multicolumn{3}{|c|}{$\mathrm{A} 1 \mathrm{~B}$} & \multicolumn{3}{|c|}{$\mathrm{A} 2$} & \multicolumn{3}{|c|}{ B1 } \\
\hline & $A_{c p}$ & $P_{C P<0}$ & $S D_{c p}$ & $A_{c p}$ & $P_{C P<0}$ & $S D_{c p}$ & $A_{c p}$ & $P_{C P<0}$ & $S D_{c p}$ & $A_{c p}$ & $P_{C P<0}$ & $S D_{c p}$ & $A_{c p}$ & $P_{C P<0}$ & $S D_{c p}$ & $A_{c p}$ & $P_{C P<0}$ & $S D_{c p}$ \\
\hline 北アメリカ & -3.9 & 62.5 & 6.6 & -3.7 & 68.4 & 7.5 & -2.3 & 66.7 & 7.6 & -5.8 & 70.8 & 9.2 & -9.0 & 73.7 & 12.3 & -4.1 & 61.9 & 7.3 \\
\hline 東ヨーロッパ & -2.0 & 62.5 & 12.8 & -2.2 & 68.4 & 11.5 & -1.2 & 61.9 & 13.8 & -2.8 & 58.3 & 17.4 & -9.9 & 84.2 & 18.0 & -0.4 & 52.4 & 13.1 \\
\hline 北ヨーロッパ & 0.9 & 58.3 & 8.5 & -0.9 & 78.9 & 4.3 & 3.0 & 33.3 & 11.7 & -1.6 & 66.7 & 10.5 & -3.4 & 68.4 & 7.8 & 1.5 & 47.6 & 9.7 \\
\hline 南ヨーロッパ & -4.9 & 79.2 & 6.5 & -4.5 & 78.9 & 5.6 & -3.8 & 76.2 & 5.1 & -7.8 & 91.7 & 7.0 & -10.9 & 94.7 & 6.1 & -7.0 & 90.5 & 6.4 \\
\hline 西ヨーロッパ & -7.7 & 75.0 & 8.6 & -6.0 & 84.2 & 6.1 & -3.8 & 81.0 & 7.7 & -11.5 & 91.7 & 9.8 & -13.3 & 100.0 & 9.5 & -7.5 & 90.5 & 9.8 \\
\hline ロシア & 15.1 & 12.5 & 16.0 & 11.0 & 15.8 & 12.5 & 8.3 & 33.3 & 14.1 & 23.9 & 8.3 & 24.2 & 22.1 & 15.8 & 30.1 & 13.7 & 19.0 & 14.2 \\
\hline 中央アメリカ & -6.4 & 83.3 & 8.1 & -7.6 & 78.9 & 7.4 & -6.4 & 76.2 & 8.1 & -14.3 & 87.5 & 10.1 & -20.0 & 100.0 & 11.4 & -9.2 & 90.5 & 9.6 \\
\hline 南アメリカ & 1.1 & 41.7 & 7.6 & 1.8 & 31.6 & 7.3 & -1.8 & 57.1 & 6.3 & 4.4 & 29.2 & 10.1 & 4.9 & 31.6 & 11.0 & 0.2 & 52.4 & 7.6 \\
\hline オセアニア & -0.7 & 58.3 & 5.9 & -3.0 & 57.9 & 7.9 & -1.6 & 66.7 & 7.1 & -5.6 & 75.0 & 7.7 & -10.7 & 89.5 & 9.4 & -4.4 & 76.2 & 9.8 \\
\hline 東アフリカ & -9.7 & 83.3 & 12.1 & -10.1 & 84.2 & 12.0 & -8.1 & 76.2 & 9.9 & -16.8 & 83.3 & 25.2 & -21.8 & 89.5 & 22.1 & -13.0 & 90.5 & 12.3 \\
\hline 中央アフリカ & 4.8 & 29.2 & 28.3 & 0.1 & 42.1 & 28.8 & 6.2 & 28.6 & 26.0 & -4.7 & 50.0 & 38.4 & -16.6 & 52.6 & 39.2 & 3.0 & 33.3 & 31.5 \\
\hline 北アフリカ & -4.7 & 66.7 & 17.3 & -4.4 & 63.2 & 20.6 & -2.7 & 61.9 & 17.0 & -6.3 & 79.2 & 20.2 & -1.6 & 68.4 & 25.8 & -5.2 & 66.7 & 21.5 \\
\hline 南アフリカ & -1.2 & 66.7 & 10.8 & -2.2 & 68.4 & 11.3 & -1.3 & 61.9 & 8.0 & -1.1 & 70.8 & 13.8 & -3.4 & 63.2 & 14.0 & -0.8 & 66.7 & 11.7 \\
\hline 西アフリカ & -33.8 & 83.3 & 35.4 & -33.6 & 89.5 & 34.2 & -26.9 & 85.7 & 33.8 & -48.8 & 75.0 & 53.7 & -50.0 & 84.2 & 59.4 & -39.5 & 85.7 & 35.8 \\
\hline 西アジア & -0.7 & 62.5 & 6.9 & -0.1 & 57.9 & 5.4 & -0.7 & 57.1 & 6.1 & -1.1 & 50.0 & 9.0 & -1.1 & 47.4 & 9.7 & -1.9 & 57.1 & 7.1 \\
\hline 東南アジア & -23.2 & 91.7 & 17.2 & -22.1 & 89.5 & 15.8 & -16.0 & 85.7 & 15.5 & -35.4 & 87.5 & 20.0 & -44.9 & 100.0 & 18.5 & -28.1 & 95.2 & 18.1 \\
\hline 南アジア & -10.8 & 83.3 & 8.7 & -11.5 & 94.7 & 7.4 & -9.2 & 90.5 & 7.4 & -14.4 & 91.7 & 12.8 & -18.1 & 94.7 & 12.5 & -13.3 & 95.2 & 9.2 \\
\hline 東アジア & 2.4 & 33.3 & 7.8 & 2.7 & 26.3 & 6.6 & 1.3 & 38.1 & 5.7 & 1.6 & 41.7 & 11.5 & 0.6 & 47.4 & 13.2 & 0.8 & 42.9 & 8.1 \\
\hline 中央アジア & -6.7 & 75.0 & 10.2 & -8.5 & 73.7 & 10.6 & -6.0 & 81.0 & 7.2 & -15.7 & 91.7 & 12.3 & -18.9 & 89.5 & 14.2 & -9.1 & 71.4 & 9.7 \\
\hline 日本 & -0.5 & 58.3 & 6.0 & -1.1 & 63.2 & 5.0 & -1.4 & 42.9 & 6.8 & -0.4 & 45.8 & 8.1 & -1.0 & 52.6 & 8.6 & -1.2 & 47.6 & 7.6 \\
\hline
\end{tabular}

表-3 各シナリオ下における近未来, 将来のトウモロコシの $A_{C P}, P_{C P<0}, S D_{C P}$

\begin{tabular}{|c|c|c|c|c|c|c|c|c|c|c|c|c|c|c|c|c|c|c|}
\hline & \multicolumn{9}{|c|}{ 近未来 } & \multicolumn{9}{|c|}{ 将来 } \\
\hline & \multicolumn{3}{|c|}{ A1B } & \multicolumn{3}{|c|}{$\mathrm{A} 2$} & \multicolumn{3}{|c|}{ B1 } & \multicolumn{3}{|c|}{ A1B } & \multicolumn{3}{|c|}{ A2 } & \multicolumn{3}{|c|}{ B1 } \\
\hline & $A_{c p}$ & $P_{C P<0}$ & $S D_{c p}$ & $A_{c p}$ & $P_{C P<0}$ & $S D_{c p}$ & $A_{c p}$ & $P_{C P<0}$ & $S D_{c p}$ & $A_{c p}$ & $P_{C P<0}$ & $S D_{c p}$ & $A_{c p}$ & $P_{C P<0}$ & $S D_{c p}$ & $A_{c p}$ & $P_{C P<0}$ & $S D_{c p}$ \\
\hline 北アメリカ & -1.0 & 58.3 & 5.7 & -1.5 & 63.2 & 6.8 & -0.8 & 61.9 & 6.2 & -1.7 & 58.3 & 8.4 & -2.5 & 52.6 & 10.3 & -1.2 & 61.9 & 7.1 \\
\hline 東ヨーロッパ & 6.8 & 45.8 & 14.9 & 7.2 & 42.1 & 15.6 & 8.0 & 28.6 & 16.4 & 9.5 & 41.7 & 21.2 & 3.4 & 52.6 & 22.2 & 11.9 & 28.6 & 16.2 \\
\hline 南ヨーロッパ & 7.3 & 37.5 & 10.3 & 8.2 & 31.6 & 11.8 & 7.9 & 23.8 & 9.8 & 9.3 & 29.2 & 12.5 & 8.3 & 31.6 & 13.7 & 10.2 & 19.0 & 12.0 \\
\hline 西ヨーロッパ & 12.0 & 25.0 & 15.2 & 14.1 & 21.1 & 18.5 & 12.6 & 23.8 & 14.7 & 16.6 & 29.2 & 22.3 & 15.0 & 36.8 & 31.3 & 18.8 & 14.3 & 19.4 \\
\hline ロシア & 21.4 & 12.5 & 29.0 & 17.2 & 10.5 & 26.5 & 12.2 & 28.6 & 17.1 & 32.5 & 12.5 & 44.1 & 31.5 & 15.8 & 62.2 & 17.8 & 14.3 & 22.3 \\
\hline カリブ & -1.8 & 58.3 & 7.3 & -1.4 & 57.9 & 7.4 & -0.6 & 71.4 & 5.7 & -3.1 & 75.0 & 9.4 & -1.7 & 73.7 & 12.6 & -1.2 & 57.1 & 7.6 \\
\hline 中央アメリナ & -1.4 & 66.7 & 3.9 & -1.1 & 47.4 & 4.4 & -1.8 & 71.4 & 3.9 & -3.7 & 70.8 & 6.0 & -3.9 & 84.2 & 7.0 & -2.0 & 61.9 & 5.6 \\
\hline 南アメリカ & -0.8 & 45.8 & 3.4 & -0.6 & 57.9 & 3.3 & -0.6 & 52.4 & 3.0 & -1.5 & 62.5 & 4.3 & -2.5 & 63.2 & 4.9 & -1.0 & 57.1 & 3.9 \\
\hline オセアニア & 1.0 & 37.5 & 6.6 & 1.6 & 36.8 & 6.9 & 0.9 & 47.6 & 8.1 & 1.1 & 45.8 & 8.6 & 0.0 & 68.4 & 9.7 & 1.4 & 57.1 & 9.5 \\
\hline 東アフリカ & -2.0 & 66.7 & 3.2 & -1.0 & 52.6 & 4.2 & 0.1 & 47.6 & 6.4 & -3.1 & 75.0 & 4.9 & -4.0 & 78.9 & 6.0 & -0.5 & 57.1 & 7.5 \\
\hline 中央アフリカ & 2.6 & 33.3 & 5.1 & 2.0 & 36.8 & 4.9 & 0.9 & 33.3 & 4.3 & 2.6 & 37.5 & 5.8 & 2.4 & 31.6 & 6.1 & 1.3 & 28.6 & 5.3 \\
\hline 北アフリカ & 0.0 & 58.3 & 4.9 & 0.8 & 47.4 & 6.8 & -0.4 & 71.4 & 7.1 & -0.8 & 70.8 & 7.4 & -0.2 & 68.4 & 11.1 & -0.7 & 61.9 & 7.1 \\
\hline 南アフリカ & -10.7 & 91.7 & 7.7 & -7.2 & 78.9 & 7.9 & -5.3 & 81.0 & 8.1 & -12.7 & 87.5 & 8.9 & -16.5 & 100. & 7.3 & -8.9 & 76.2 & 9.7 \\
\hline 西アフリカ & 0.4 & 45.8 & 5.5 & -0.4 & 63.2 & 5.0 & 0.7 & 61.9 & 5.7 & 2.5 & 45.8 & 7.0 & 1.7 & 47.4 & 7.1 & 0.8 & 47.6 & 4.8 \\
\hline 西アジア & 0.0 & 58.3 & 5.6 & 0.5 & 57.9 & 4.8 & 1.3 & 38.1 & 5.2 & -0.3 & 50.0 & 5.8 & -0.4 & 42.1 & 6.4 & 0.5 & 47.6 & 7.0 \\
\hline 東南アジア & 0.2 & 54.2 & 3.9 & 1.6 & 36.8 & 3.9 & 0.6 & 47.6 & 4.1 & 1.8 & 37.5 & 4.9 & 3.5 & 42.1 & 6.3 & 0.6 & 42.9 & 4.8 \\
\hline 南アジア & -2.0 & 79.2 & 3.0 & -0.9 & 63.2 & 3.5 & -1.3 & 76.2 & 2.6 & -4.0 & 87.5 & 3.7 & -5.1 & 78.9 & 4.1 & -3.1 & 90.5 & 2.5 \\
\hline 東アジア & 9.3 & 20.8 & 10.0 & 8.4 & 5.3 & 8.5 & 6.3 & 9.5 & 6.8 & 12.0 & 16.7 & 12.4 & 14.8 & 10.5 & 14.1 & 8.8 & 14.3 & 9.2 \\
\hline 中央アジア & 3.5 & 45.8 & 12.0 & 4.1 & 42.1 & 12.9 & 1.3 & 42.9 & 9.0 & -1.7 & 58.3 & 14.3 & -3.8 & 63.2 & 15.8 & 2.7 & 42.9 & 11.0 \\
\hline 日本 & -3.6 & 62.5 & 7.9 & -2.9 & 63.2 & 7.9 & -3.1 & 66.7 & 6.7 & -5.9 & 62.5 & 12.2 & -6.9 & 63.2 & 14.0 & -2.9 & 61.9 & 9.8 \\
\hline
\end{tabular}

トウモロコシの世界生産量は, 近未来の全シナリオ平 均で7.6\%, 将来で同10.2\%増加する結果となった. 特に, 東アジアにおける生産量増加による寄与が大きい. 東ア ジアの $A_{C P}$ は，近未来のA1Bシナリオ下で9.3\%, A2で8.4\%, B1で6.3\%の増加となり，将来ではそれぞれ12.0, 14.8, 8.8\% の増加を示した．本結果は，中国において2030年の生産 量がモデル間平均で7\%減少するとしたLobell et al. ${ }^{15}$ の結
果とは逆の傾向を示すものである. 南アジアの $A_{C P}$ は近 未来, 将来ともに全シナリオ下で負を示しており, Lobell et al. ${ }^{15}$ と同様の傾向を示した. 北アメリカにおける $A_{c p}$ はA1B, A2, B1シナリオ下の近未来でそれぞれ-1.0,-1.5, $-0.8 \%$ となり, 将来ではそれぞれ-1.7, - 2.5, - - . 2\%と生産量 は微减する結果となり，減少を示寸確率は50\%を超える 結果となった. 南アメリカでも北アメリカと同様に生産 

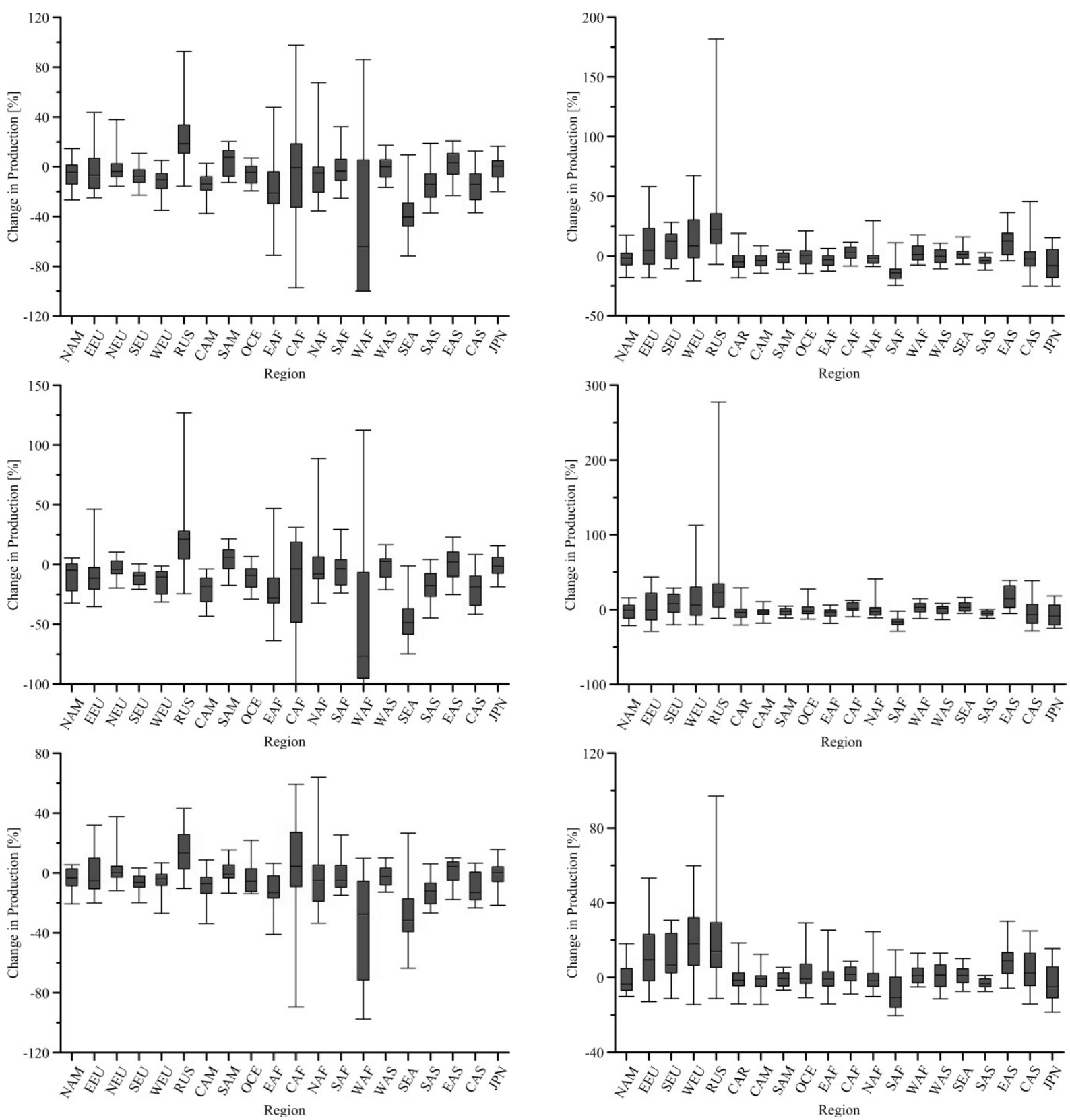

図-1 世界の地域別に見る将来の生産量変化率（左：コムギ，右：トウモロコシ，上段: A1B, 中段: A2, 下段: B1，略語は表-2, 表3の地域名にそれぞれ対応)

量は近未来, 将来とも微减を示寸結果となり，両域とも $S D_{C P}$ の值は他の地域と比較して相対的に小さい部類に 入り，比較的不確害性は小さいと言える. 一方，ロシア では将来で15\%以上の増加を示すが，モデル間のばらつ きが大きく不確実性が大きい（表-2, 図-1）。ヨーロッ パでは全域において, 将来の生産量は増加する結果とな った. 以上のことから，トウモロコシは現在の主要生産 域での生産量減少は微减な幅にとどまり，温暖化による 地球規模での大幅な生産量の減少が生じにくい作物種の 一つであると考えられる。.また， $A_{C P}$ の地域間標準偏差 は，将来においてA1Bが9.5\%, A2が9.7\%, B1が7.0\%となっ た。このことから，生産量の絶対的な地域差を考えない 場合，B1シナリオでは将来における生産量変化率のば
らつき，つまり不確実性の幅が最も小さいと言える.

\section{4. まとめ}

本研究では, SRES A1B, A2, B1シナリオ下の複数の GCMマルチ気候モデル出力值を用いて, 現在（19801999年），近未来（2040-2059年），将来（2080-2099年） の生産量を農業収量算定モデルを用いて見積もり, 気候 変動が農業生産に与える影響を不確実性を考慮して評価 した. その結果，コムギは現在の主要生産地域である東 アジアでは生産量に大きな変化はないものの, 南アジア やヨーロッパでは生産量が減少することが予想される結 
果となった。 また，トウモロコシでは，東アジアにおい て生産量が増加する結果となり, 北アメリカや南アメリ カでは将来における生産量は減少するものの，その減少 幅は小さいことからトウモロコシの世界生産量は，全シ ナリオ平均で将来 $10.2 \%$ 増加する結果を得た。 各シナリ オ下における地域ごとの生産量変化率のばらつきを見る と，B1シナリオでは，近未来および将来における地域 間の生産量変化率の標準偏差，つまり不確実性の幅（ば らつき）が最もささなった.

今後として，極端気象を考慮した上での温暖化が農業 生産に与える影響やその適応策について考えていきたい.

\section{参考文献}

1) Takahashi K., Harasawa H. and Matsuoka Y.: Climate change impact on global crop production, Journal of Global Environmental Engineering, Vol.3, pp.145-161, 1997.

2) Masutomi Y., Takahashi K., Harasawa H. and Matsuoka Y.: Impact assessment of climate change on rice production in Asia in comprehensive consideration of process/parameter uncertainty in general circulation models, Agriculture, Ecosystems and Environment, Vol.131, pp.281-291, 2009.

3) Tan G. and Shibasaki R.: Global estimation of crop productivity and the impacts of global warming by GIS and EPIC integration, Ecological Modelling, Vol.168, pp.357-370, 2003.

4) Pany M.L., Rosenzweig C., Iglesias A., Livermore M. and Fischer G.: Effects of climate change on global food production under SRES emissions and soci-economic scenarios, Global Environmental Change, Vol.14, pp.53-67, 2004.

5) Tatsumi K., Yamashiki Y., Roverto V.S., Takara K., Matsuoka Y., Takahashi K., Maruyama K. and Kawahara N.: Estimation of potential changes in cereals production under climate change scenarios, Hydrological Processes, Vol.25, pp.2715-2725, 2011.
6) Meehl G.A., Covey C., Delworth T., Latif M., McAvaney B., Mitchell J.F.B., Stouffer R.J and Taylor K.E.: The WCRP CMIP3 Multimodel Dataset: a nwe era in climate change research, Bulletin American Meteorological Society, Vol.88, pp.1383-1394, 2007.

7) Mitchell T.D. and Jones P.D.: An improved method of constructing a database of monthly climate observations and associated high-resolution grids, International Journal of Climatology, Vol.25, pp.693-712, 2005.

8) USGS.: GTOPO30. United States Geological Survey, Available at http:/www1.gsi.go.jp/geowww/globalmap-gsi/gtopo30/gtopo30.html

9) FAO:: The Digital Soil Map of the World and Derived Soil Properties, Version 3.5, Food and Agriculture Organization, CD-ROM, 1995.

10) Döll, P. and Siebert S.: A digital map of inigated areas, International Commission on Irrigation and Drainage, VOl.49, No.2, pp.55-66, 2000.

11) Sacks W.J., Deryng D., Foley J.A. and Ramankutty N.: Crop planting dates: an analysis of global pattems, Global Ecology and Biogeography, Vol.19,pp.607-620, 2010.

12) 村井啓朗, 高橋潔, 増井利彦, 原沢英夫, 松岡譲: 適応策を考慮 した上での温暖化が農業潜在生産性に及ぼす影響の評価, 環 境システム研究論文集, Vol.33,pp.97-104, 2005.

13) 辰己賢一: 作物収量算定モデルの高精度化と気候変動が農業 生産に与える影響の定量的分析に関する研究, 京都大学大学 院工学研究科学位論文, 2012.

14) Portman F.T., Siebert S. and Döll P: MIRCA2000-Global monthly inigated and rainfed crop areas around the yar 2000: A new high-resolution data set for agricultural and hydrological modeling, Global Biogeochemical cycles, Vol.24, GB1011, 2010.

15) Lobell D.B.: Prioritizing Climate Change Adaptation Needs for Food Security in 2030, Science, Vol.319, pp.607-610, 2008.

(2012. 4. 20 受付) (2012.6. 18 受理)

Impact assessment of climate change on wheat and maize production on consideration of GCM uncertainty

\author{
Kenichi TATSUMI ${ }^{1}$, Yosuke YAMASHIKI ${ }^{1}$ and Kaoru TAKARA ${ }^{1}$
}

${ }^{1}$ Disaster Prevention Research Institute, Kyoto University

This paper uses the iGAEZ (improved Global Agro-Ecological Zones) model for simulating wheat and maize yields on a global scale. We estimated the future agricultural production under climate change, based on iGAEZ model and climate projection for 2040-2059, 2080-2099 from general circulation models (A1B: 24, A2:19, B1:22 models) using the CMIP3 multi-model dataset. Results indicate wheat production in whole world have decreased in the near future and the future under the all scenarios. In addition, East Asia will likely get positive impacts on wheat production in the future. Moreover, it is found that reduction in maize productions on North and South America remains within small range. Under the SRES B1 scenario, developed and developing regions exhibit less contrast in crop yield changes, with the B1 future crop yield changes being slightly more favorable than those of the A1B, A2. B1 scenario is being relatively east to plan agricultural adaptation for long-term food supply and demand. 